\title{
OUTCOME OF CAPITAL INVESTMENT ON LABOR PRODUCTIVITY IN AGRICULTURE SECTOR OF UKRAINE
}

\author{
Viktoriya Onegina \\ Kharkiv Petro Vasylenko National University of Agriculture, Ukraine \\ Nikolay Megits \\ Webster University, MO, USA \\ Vitalina Antoshchenkova \\ Kharkiv Petro Vasylenko National University of Agriculture, Ukraine \\ Oleksandr Boblovskiy \\ Kharkiv Petro Vasylenko National University of Agriculture, Ukraine
}

\begin{abstract}
Ukraine's agricultural sector accounts for 12\% of the country's GDP and its output is continuously growing. For six consecutive years (2013-2018), Ukraine harvested over 60 million tons of grain annually, and 2018 export of ag commodities reached $\$ 18.6$ billion. (State Fiscal Service, 2020). The anticipated land reform envisions lifting the moratorium on the agricultural land sale, which is expected to encourage capital investments in ag. The article analyzes the trends of investment opportunities in the Ukrainian ag sector for the last decade. The regression analysis confirmed that the function of labor productivity depended on the value of fixed capital per worker and yield of grain. The influence of productivity growth on the increase of price of land is evaluated. As the U.S. investment in ag machinery export to Ukraine plays a significant role, we evaluated the overall effect on the current level of labor productivity in the Ukrainian agribusiness, comparing it with the U.S. farming outcome.
\end{abstract}

Keywords: productivity of labor, agriculture, investment, fixed capital, employee, economic growth, Ukraine

DOI: http://dx.doi.org/10.15549/jeecar.v7i1.355

\section{INTRODUCTION}

Increasing labor productivity in agriculture and reducing the time needed for food production build up the foundation for economic growth, for the steps of society to a higher level of socio-economic progress. The crucial role of productivity growth in agriculture to achieve the goals of sustainable development (Resolution of U.N. (2015) "Transforming our world: the 2030 Agenda for Sustainable Development") was announced by experts of 
the Food and Agricultural Organization (FAO) of United Nations. "Increase productivity, employment and value addition in the food system" as the first significant area as proof of 20 actions have been offered (FAO, 2018) to integrate three dimensions of sustainable development - economic growth, social inclusion, and environmental protection.

Ukraine has a rich resource potential of agrarian production, and agriculture is vitally essential for the Ukrainian economy. Statistics indicate: $13.3 \%$ of gross value added was created, $10.0 \%$ of hired workers, $17.6 \%$ of the total employed worked in agriculture in Ukraine in 2015-2017 (State Statistics Service of Ukraine, 2018). The increase of labor productivity in agriculture is necessary to reduce the imbalance between the share of agricultural inputs in gross value added and employment in this sector of the Ukrainian economy.

One of the most effective ways to promote productivity is utilizing a capital investment (domestic and foreign). But the investment is well known to be very sensitive to political and macroeconomic stability. Analysis of the dynamics of investment and labor productivity will assist in specifying the trends, relationships, and factors of influence on these processes during the macroeconomic crisis.

\section{LITERATURE REVIEW}

In the latest research on labor productivity in agriculture in Ukraine, Vitvitskyi (2018) paid attention to the development of the institutional environment for managing labor productivity, the need for the appropriate programs to improve it. Also, Vitvitskyi and Avramenko (2018) concluded that productivity and competitiveness as integrated interrelated economic categories involve the process of interaction and harmonization of such institutional factors as an investment in innovation and quality of human capital. But their research does not include an analysis of trends of investment, non-current assets, and labor productivity. Zadorozhna (2014) focused on the theoretical principles of forming the Agro Industries clusters in the context of the innovative and productivity growth aspect. One of Ukraine's primary sources of economic revenue, the country's agro-industrial sector, was shown to be perhaps the most vulnerable branch of economy in the times of political and social turbulence. Lupenko and Zakharchuk (2018) investigated the dynamics of investment in agriculture in Ukraine, without highlighting its link with labor productivity. Diyesperov (2003) concentrated on labor productivity dynamics and its factors in Ukraine, but since that time, structural, innovative, and global transformations have influenced Ukrainian agriculture.

Kawagoe, Hayami, and Ruttan (1985) identified the sources of differences in labor productivity in agriculture between developed countries and less developed countries, by estimating an aggregate agricultural production function based on data for 1960, 1970, and 1980. Restuccia, Yang, and Zhu (2008) revealed that a high share of employment and low labor productivity in agriculture are mainly responsible for low aggregate productivity in developing countries. Herrendorf and Schoellman (2015) stressed that labor productivity in agriculture is considerably lower than in the rest of the economy in developing countries. Also, they assessed if in the U.S., labor in the ag sector was misallocated and if productivity was mis measured.

Blanco and Raurichy (2018) also paid attention to the differences in labor productivity between developed and developing countries, which is substantially larger in agriculture than in non-agriculture. They argued that structural change within agricultural sectors explained part of these differences and considered two agrarian areas that are differentiated only by the capital intensity.

Yasmin, Refae, and Eletter (2019) considered sectoral productivity in the Hungarian economy. They assumed that sectoral capital accumulation, labor reallocation across sectors, and total factor productivity contribute to sectoral performance. They evaluated a key area of ag sector, which have an essential place in the Hungarian economy, and need continuous monitoring and improvement of planning to enhance productivity to be able to attract foreign direct investments.

In his study, Iscan (2012) addresses the productivity differences across producers, the 
welfare consequences of reallocating labor from lesser to more productive producers. He built a multi-sector, multi-region general equilibrium model with the land as a region-specific factor using state-level U.S. data from 1960 to 2004, a period with a considerable reallocation of labor out of agriculture. Restuccia and Rogerson (2013) explained a large portion of differences in output per capita across countries by differences in total factor productivity, reallocation of the factors across various production units. Restuccia (2016) argued that labor productivity in agriculture was extremely low in emerging countries. He defined, as a source of this productivity problem, a small operational scale of farms in developing countries, which serves to discourage further the adoption of modern technologies, intermediate inputs, and other productivityenhancing investments. Also, he proposed that at the core of the productivity problem in agriculture in emerging countries is resource misallocation. Particularly, this misallocation is associated with imperfections in regards to land markets. Chen, Restuccia, and SantaeulàliaLlopis (2019) investigated the effects of land markets on resource allocation and agricultural productivity (using experience of land reform in Ethiopia).

FAO experts (2012) analyzed investment and labor productivity in agriculture in many countries in 2005-2007. The results of their research confirm the direct correlation between the amount of investment, capital, and capital per employee in agriculture and the production of agricultural gross domestic product per employee. According to their estimates, in 2005-2007, high-income countries had average agricultural capital stock per worker U.S. \$89 800 , while low and middle-income countries $\$ 2600$, the world (average) - \$4000. But the trends of investment, capital stock, and labor productivity in the high turbulent economy were not included in their horizontal analysis.

OECD researchers (2018) assume Total Factor Productivity (TFP) as the most comprehensive productivity indicator. In recent decades, they showed productivity improvements have driven considerable growth in agricultural production. Still, there are significant differences in productivity growth between countries and by farm type, size, and region. In one of OECD/ FAO's latest reports (2019), agricultural innovation has been considered as the central driving force to transform agri-food systems into a more productive, competitive, and sustainable sector.

Fuglie, MacDonald, and Ball (2007) stressed that gains in productivity had been a driving force for growth in U.S. agriculture and assessed the increase in TFP in agriculture, as well as growth rate in labor productivity for 1948-2004, sources of labor productivity growth. Researchers of ERS/ USDA (Wang, Heisey, Schimmelpfennig, and Ball 2015) defined the trends of capital, land, and labor used in agriculture of the USA in 1948-2011 (13) as well patterns of TFP. They evaluated that between 1948 and 2011, labor productivity increased by nearly 16 times in agriculture in the U.S. Alston, Beddow and Pardey, (2009) revealed the links between expenditures on agricultural research and productivity, and confirmed expenditures importance for the productivity growth in the long-run period.

Thus, the investigation of investment and labor productivity in agriculture is reflected in many scientific articles and reports. But the trends and relationship between these critical determinants of economic development have not been defined for the unstable and emerging economy of Ukraine.

\section{DATA AND METHODOLOGY OF THE RESEARCH}

Our research is carried out based on statistical data of the State Statistics Service of Ukraine, OECD, FAO, the National Agricultural Statistics Service (NASS) of USDA, and farm-level surveys. Specific details of trend estimations and horizontal comparisons of statistical data in Ukrainian agriculture are related to the fact that the State Statistics Service of Ukraine provides information on investment, fixed assets, employment in agriculture, forestry, and fisheries with different coverage of these economic sectors. We take into account these peculiarities of data representation and clarify the scope of the industry to determine trends.

It is necessary to note that agriculture is structurally heterogeneous in Ukraine. About 40 percent of the agricultural product (39.5 percent 
in 2017) is produced in households, for which low capital use and low productivity are inherent. Therefore, a comparative analysis of labor productivity has been carried out for the agricultural industry and separately for the agrarian enterprises of Ukraine.

Particular clarification was made for the data concerning capital stock in Ukrainian agriculture. The estimates of agricultural capital stock presented in the FAO reports (2012) are based on the data on inventories of capital assets that include land development, livestock, machinery and equipment, plantation crops, and buildings for livestock. This inventoriesbased approach provides comparable estimates of agricultural capital stock for a large number of countries. However, it has some limitations; in particular, it does not cover all relevant assets, and it cannot account for differences in the quality of assets across countries. Due to the attitude of the State Statistics Service of Ukraine (2018), the value of the "basic" (means "fixed") assets is represented in statistical publications. In agriculture, it includes the benefit of all noncurrent assets that are used for economic activity for more than one year (buildings, machinery, tools, and equipment). But it does not include the value of land used in agricultural production (due to the peculiarities of the current stage of land reform in Ukraine). The structure of "basic" (fixed) assets is similar to the combined fixed capital (machinery, tools, equipment, and factory buildings) used by Cobb and Duglas (1928) for their production function for manufacturing in the United States. Noncurrent assets of agricultural enterprises also include long-term biological assets (for example, breeding livestock). Still, they are not included in "basic" (fixed) assets, as reflected in the State Statistical Service of Ukraine database. In this research, the value of "basic" (fixed) assets will be considered as a fixed capital of agricultural producers.

For the study, we applied the abstract-logical method and the method of generalization techniques. Also, we used an index method, trend analysis, correlation and regression analysis, and comparative analysis.

\section{FINDINGS: TRENDS OF INVESTMENT, FIXED CAPITAL AND LABOUR PRODUCTIVITY}

Over the past ten years, the economy of Ukraine has undergone significant fluctuations in both GDP and volume of agricultural production. These facts confirm the trends of GDP, the volume of agricultural products in general, and the bulk of farming products at agrarian enterprises and households, the indices of which are given in Figure 1.

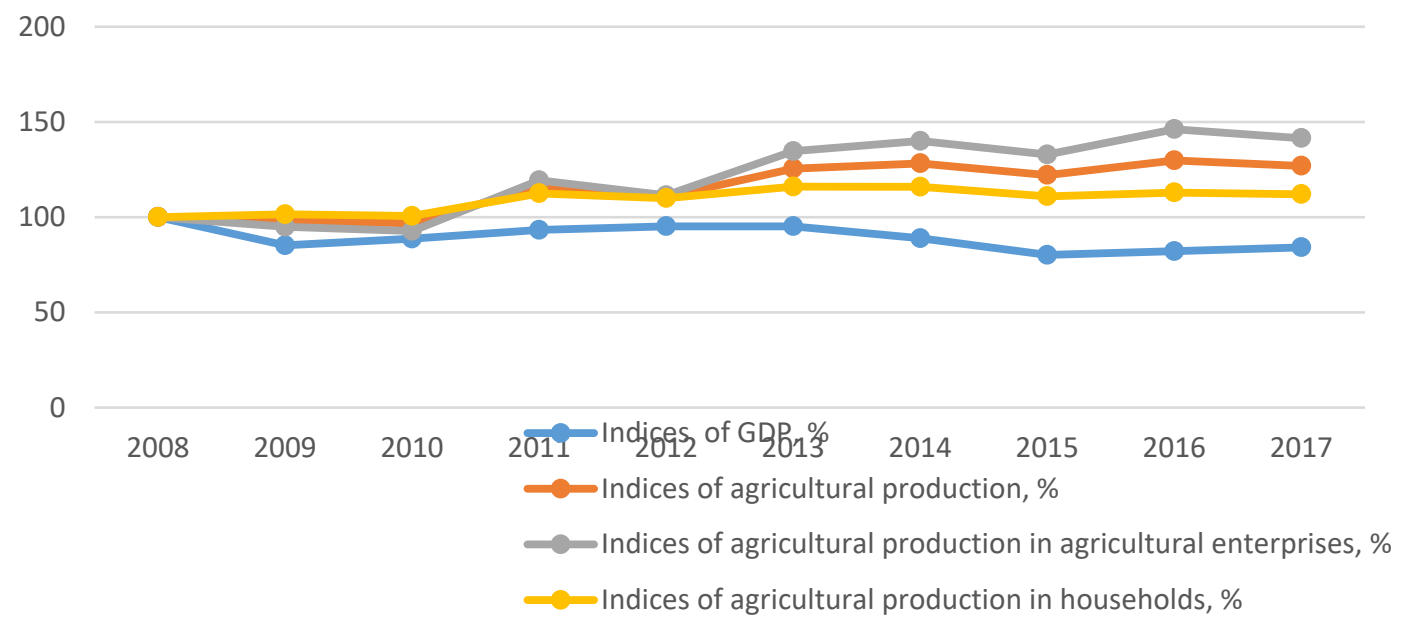

Figure 1. Indices of GDP and gross agricultural product, \% (2008 - 100\%)

Source: Developed by authors using data of State Statistical Service of Ukraine 
The significant GDP reduction occurred in Ukraine in 2009 (by $14.8 \%$ compared to the previous year), in 2014 (by 6.6\%), and 2015 (by $9.8 \%$ ). But the decline in agricultural production was not so significant in 2009 (only $1.8 \%$ ), and in 2015 and 2016, agricultural production even increased. In 2017, the volume of GDP did not restore at the level of 2008 (GDP index in 2017 to 2008 equaled to $84.2 \%$ ). The volume of agricultural production was greater than its level in 2008 by almost 30\% (at agricultural enterprises by $46.2 \%$ ) in 2016, but in 2017 , against the GDP growth, output in agriculture decreased by $2.2 \%$.

There were significant fluctuations in agricultural output. The coefficient of variation of indices of agricultural production (Table 1 ) in total was 1.3 times, and, at agricultural enterprises, 2.1 times as high as the coefficient of variation of GDP indices for 2008-2017, but agrarian production dynamics, on the contrary, demonstrated growth. The agricultural production in households was more stable, but its growth was smaller compared to the increase in output at agricultural enterprises.

Table 1. Coefficient of variation of GDP and agricultural output indices in Ukraine in 20082017

\begin{tabular}{|l|l|}
\hline Indices & Coefficient \\
\hline GDP & 0.068 \\
\hline Agricultural production & 0.089 \\
\hline $\begin{array}{l}\text { Agricultural production at } \\
\text { agricultural enterprises }\end{array}$ & 0.145 \\
\hline $\begin{array}{l}\text { Agricultural production in } \\
\text { households }\end{array}$ & 0.045 \\
\hline
\end{tabular}

Source: authors' calculations
The correlation coefficient between the indices of GDP and gross agricultural output at the level of 0.450 shows a relatively weak correlation between these indicators. It gives grounds to assume the significant influence of other factors on the dynamics of production in agriculture.

In the investigated period, the volumes of investments in agriculture in Ukraine fluctuated, but they (estimated in national currency) had dynamism to increase, and in 2017 their volume was 3.9 times as high as in 2008 and compared with the level of the crisis year 2009 - 6.9 times (Figure 2). In terms of U.S. dollars, the volume of investment in agriculture in Ukraine did not have such a sharp increase, and their annual value was the largest in 2008 (\$ 3.2 billion). Afterward, it ranged from \$ 1.2 billion (2009) to $\$ 2.4$ billion (2017).

The correlation test based on the GDP and investment recorded in agriculture confirmed that the dynamics of GDP influenced the investment in this period. The correlation coefficient $(0.822)$ between the rates of GDP growth and rates of investment growth (in U.S. dollars) shows a fairly close correlation between them. The correlation coefficient between the rates of GDP growth and investments (in Ukrainian national currency - Ukrainian hryvnia, UAH) is much lower (0.514). Being dependent on the growth trend of the economy as a whole, the dynamics of investment in agriculture, as our correlation analysis confirms, was also influenced by such factors as the prices for agricultural products and the number of profits received by agricultural enterprises. 


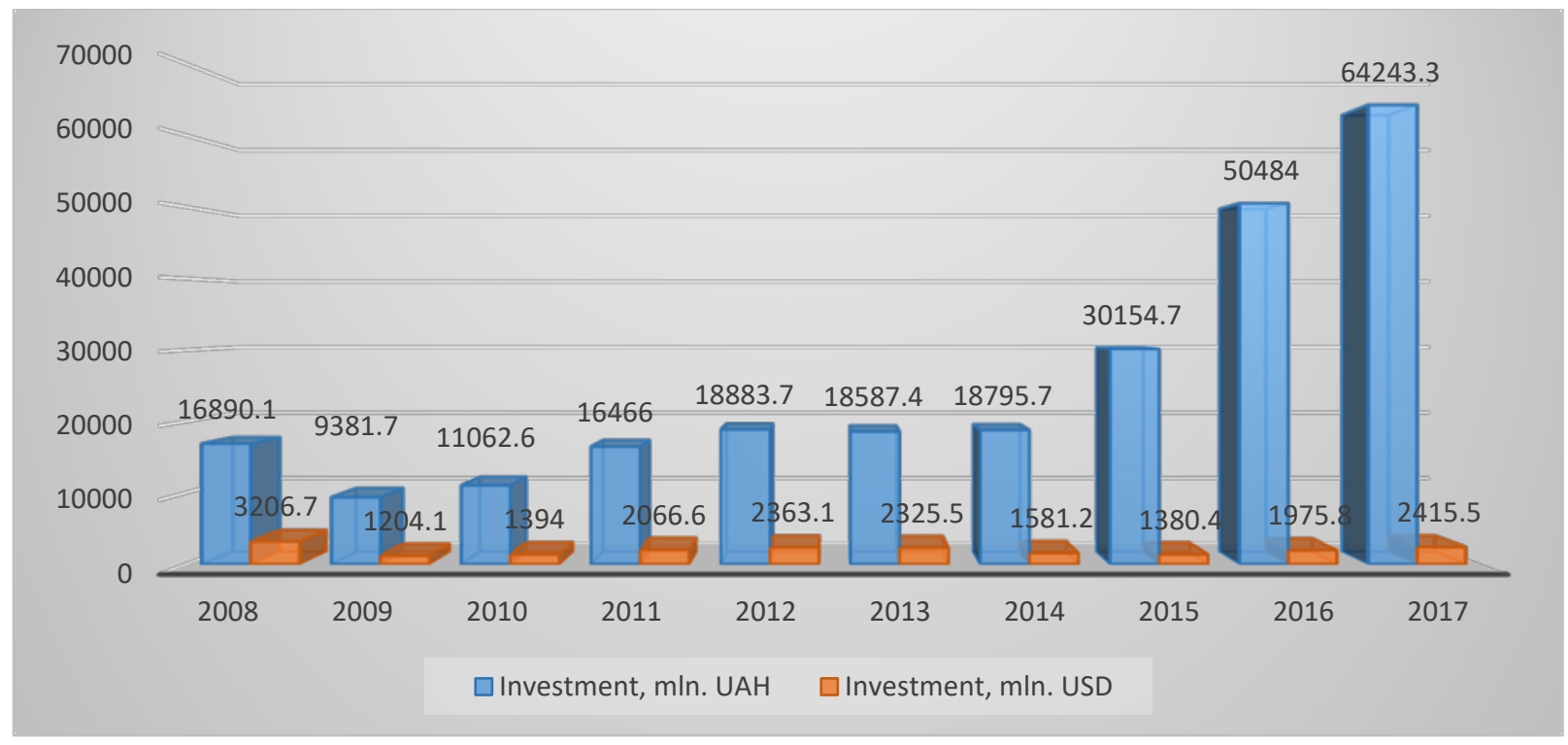

Figure 2. Capital investment in agriculture in Ukraine

Source: Developed by authors using data of State Statistical Service of Ukraine

The correlation coefficient between the amount of profit and investment indices for the same year is equal to 0.797 and 0.937 for indicators with a one-year lag for investment. The correlation coefficient between the price indices and the indices of investments equals 0.303 for the same year index, and 0.721 with a slowdown in one year due to our estimate. Despite gradually decreasing the prices for agricultural products in the world market during 2012-2016, and slightly increasing in
2017 (Figure 3), the depreciation of the Ukrainian national currency was very significant (5.0 times for 2008-2017). These factors led to an increase in the prices for agricultural products in the domestic market of Ukraine. The cost of the ag product was 4.2 times higher in 2017 than in 2008. Favorable price dynamics of farming products and financial results of agrarian enterprises induced and provided sources of investment for the next year.

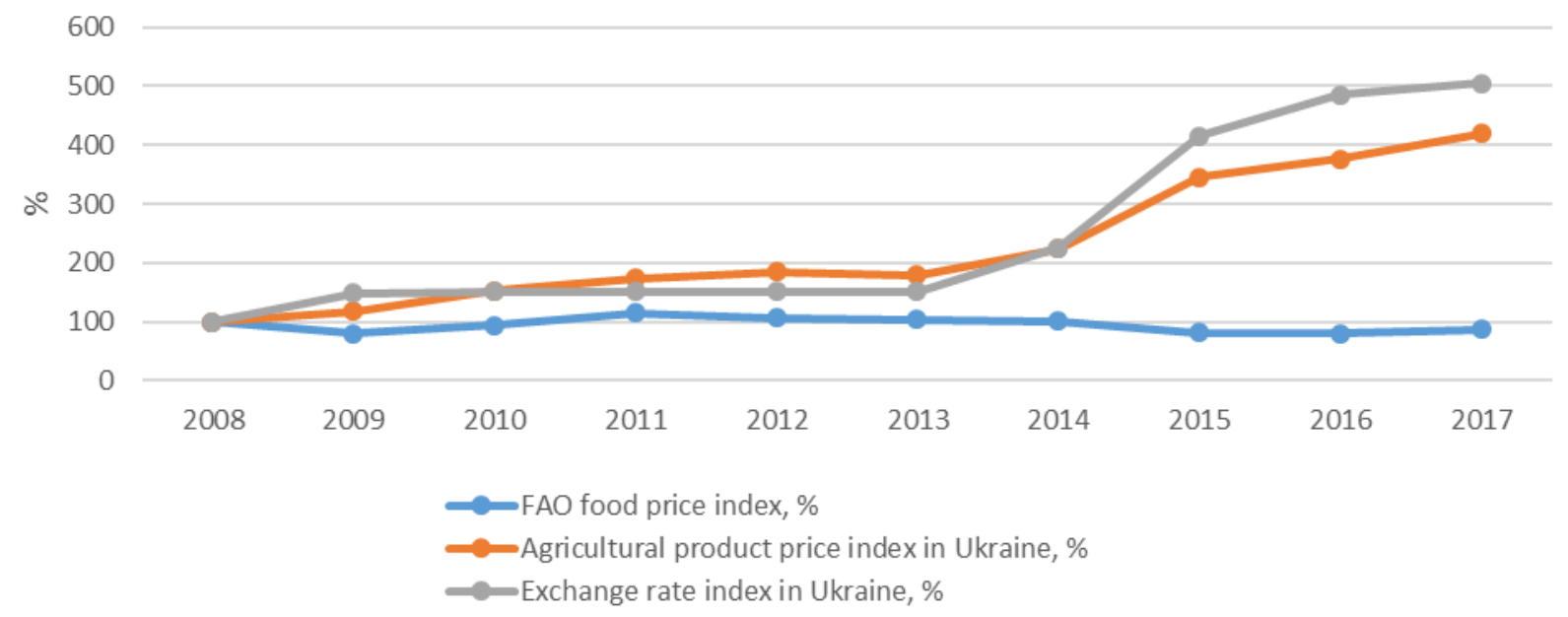

Figure 3. Price and exchange rate indices

Source: Developed by authors using the data of FAO and State Statistical Service of Ukraine 
The processes of investing in agriculture led to an increase in the value of fixed capital in agriculture. Indeed, statistical data confirm this growth (Figure 4). The value of fixed capital in agriculture in 2017 was 3.1 times higher than in 2008 (it increased from UAH 97.8 billion to UAH 305.0 billion). But the conversion of the value of fixed assets in agriculture into U.S. dollars testifies to its decrease during this period (from $\$ 18.6$ billion to $\$ 11.5$ billion). The five-time depreciation of the Ukrainian national currency during this decade outstripped the investment process and increased the value of the fixed capital in agriculture (measured in national currency).

The agricultural producers purchased not only imported machinery and equipment but also domestic ones, the prices of which were raised not so fast as the depreciation of the Ukrainian currency. Also, the government program of partial subsidies for purchasing domestic agricultural machinery contributed to the purchasing of the machinery of Ukrainian production. In 2017 the value of imported agricultural machinery and equipment was estimated at $\$ 960.4 \mathrm{mln}$. (Zakharchuk, 2019). For example, new tractors of John Deere (biggest importer of agricultural machinery in Ukraine) made up $5.2 \%$ of all purchased ones; the grain combines $-5.4 \%$ in 2017 . Therefore, in agriculture (the study did not take into account the occupied territories) there were the processes of the real increase of fixed capital. Under moratoria on the free operation of agricultural land market agricultural producers invested in machinery and equipment. The level of depreciation of the fixed assets has dropped in agriculture in Ukraine from 55.1\% in 2008 to $35.4 \%$ in 2017.

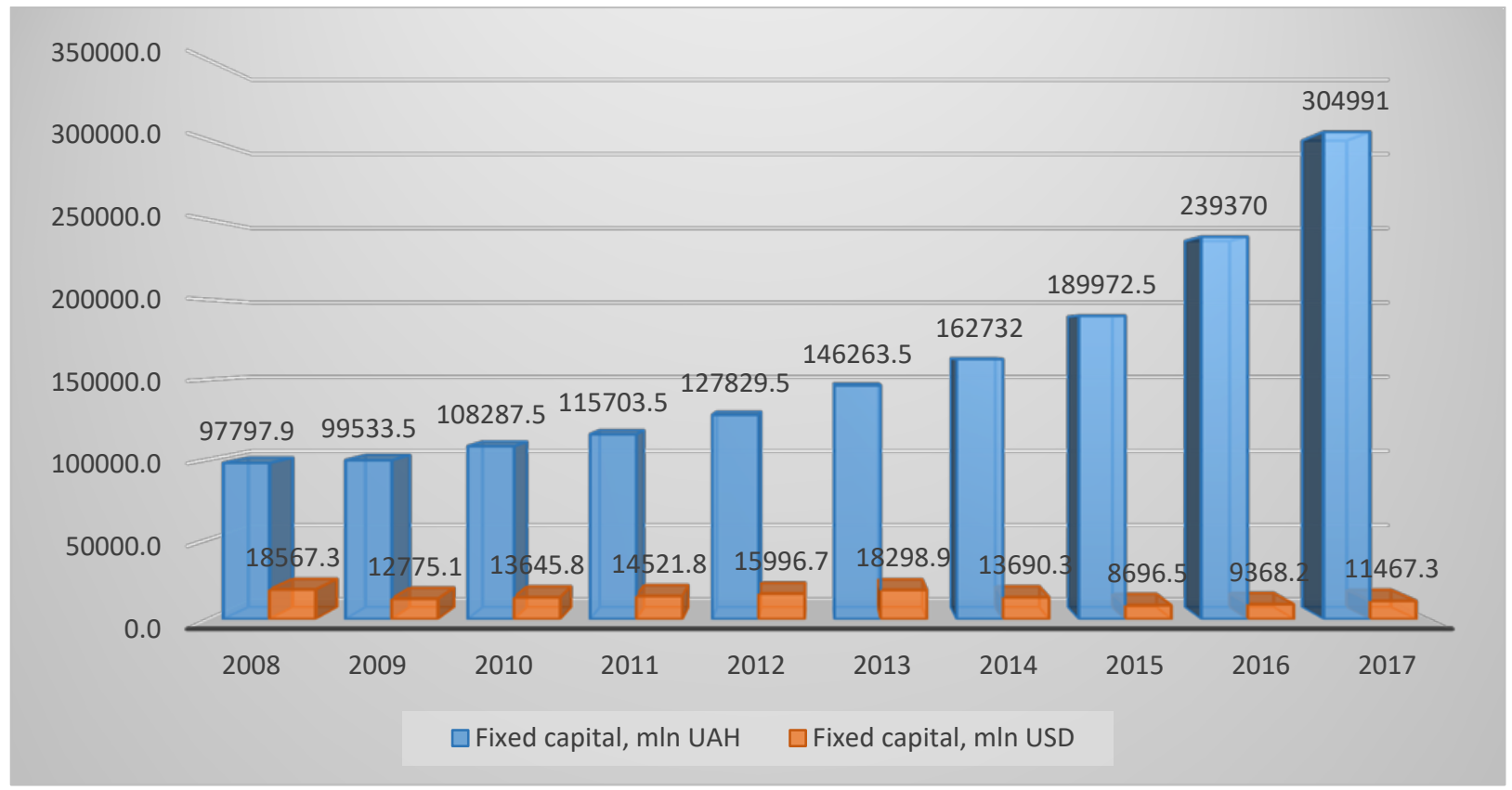

Figure 4. The average annual value of fixed capital in agriculture in Ukraine Source: Developed by authors using data of State Statistical Service of Ukraine

Increasing the value of fixed capital and reducing the number of employees led to an increase in fixed capital stock per worker in agriculture. In 2008-2017, the number of persons employed in agriculture in Ukraine decreased by $13.9 \%$ (from 3.3 million to 2.9 million), and the number of hired workers at agricultural enterprises decreased by $28.9 \%$ (from 698 thousand to 496 thousand).

The achieved level and dynamics of the ratio of fixed capital-labor was estimated, taking into 
account both the number of employed in agriculture and the number of hired workers of agricultural enterprises. This double estimate has been done due to the heterogeneous structure of agriculture in Ukraine. The biggest part of the fixed capital of agriculture (about $80 \%$ ) is concentrated in agricultural enterprises, while the households use mostly primitive low productive tools in the production. In $2017,8.2 \%$ of households cultivated the land exclusively by hand and only $7.5 \%$ by tractor, others - by hand and using tractors, horses, and oxen. The results of our assessment of fixed capital per worker in agriculture in Ukraine are presented in Table 2.

Table 2. The fixed capital per employed person in agriculture and per hired worker of agricultural enterprises

\begin{tabular}{|l|l|l|l|l|l|l|l|l|l|l|}
\hline Indicator & 2008 & 2009 & 2010 & 2011 & 2012 & 2013 & 2014 & 2015 & 2016 & 2017 \\
\hline $\begin{array}{l}\text { Fixed capital } \\
\text { per employed } \\
\text { person, UAH } \\
\text { thousand }\end{array}$ & 29.5 & 31.7 & 34.9 & 34.0 & 36.6 & 41.0 & 52.8 & 66.4 & 83.7 & 106.9 \\
\hline $\begin{array}{l}\text { Fixed capital } \\
\text { per employed } \\
\text { person, \$ } \\
\text { thousand }\end{array}$ & 5.6 & 4.1 & 4.4 & 4.3 & 4.6 & 5.1 & 4.4 & 3.0 & 3.3 & 4.0 \\
\hline $\begin{array}{l}\text { Fixed capital } \\
\text { per hired } \\
\text { worker, UAH } \\
\text { thousand }\end{array}$ & 112.1 & 118.5 & 134.3 & 146.4 & 164.5 & 202.2 & 246.1 & 303.4 & 373.1 & 491.8 \\
\hline $\begin{array}{l}\text { Fixed capital } \\
\text { per hired } \\
\text { worker, \$ } \\
\text { thousand }\end{array}$ & 21.3 & 15.2 & 16.9 & 18.4 & 20.6 & 25.3 & 20.7 & 13.9 & 14.6 & 18.5 \\
\hline
\end{tabular}

Source: authors' calculations

The calculation of the indicators of the fixed capital-worker ratio showed, firstly, the growth of these indicators for 2008-2017, in agriculture (3.6 times, estimated in the Ukrainian currency), and in agricultural enterprises (4.4 times). Secondly, a significant excess (4.6 times) of the capital-labor ratio in agricultural enterprises compared with its average level in agriculture as a whole. Thirdly, the level of fixed capital-labor ratio in U.S. dollars had a significant reduction in the crisis years and subsequent gradual growth. In 2017, in agriculture as a whole and agricultural enterprises, the levels of fixed capital per unit of labor converted in U.S. dollars did not reach their levels in 2008. Comparison of capital-labor ratio in Ukraine (2017) with the calculations of FAO experts (2012) testified that the capital stock per one employed in Ukraine is considerably inferior to the level of developed countries. Still, agricultural enterprises in this indicator have reached the average level of Europe and Central Asia, while, in general, the level of capital-labor ratio in agriculture was on the average world level.

The growth of capital positively affected the growth of labor productivity in agriculture in Ukraine (Table 3 ). The labor productivity has more than doubled in Ukrainian agricultural enterprises in the period 2008-2017. 
Table 3. Labor productivity in agricultural enterprises in Ukraine

\begin{tabular}{|l|l|l|l|}
\hline Year & $\begin{array}{l}\text { Per one employee in agricultural } \\
\text { production, in 2010 prices, hryvnia }\end{array}$ & $\begin{array}{l}\text { Percent to the } \\
\text { previous year }\end{array}$ & Percent to 2008 \\
\hline 2008 & 127372.5 & 143.8 & 100.0 \\
\hline 2009 & 131332.0 & 103.1 & 103.1 \\
\hline 2010 & 132680.4 & 101.0 & 104.2 \\
\hline 2011 & 165229.0 & 124.5 & 130.0 \\
\hline 2012 & 159679.0 & 96.6 & 125.4 \\
\hline 2013 & 201216.9 & 126.0 & 158.0 \\
\hline 2014 & 227753.4 & 109.1 & 178.8 \\
\hline 2015 & 223309.9 & 98.0 & 175.3 \\
\hline 2016 & 275317.8 & 123.3 & 216.2 \\
\hline 2017 & 271491.4 & 98.6 & 213.1 \\
\hline
\end{tabular}

Source: data of State Statistics Service of Ukraine and author's calculations

The correlation coefficient between labor productivity in 2010 prices and the level of fixed capital per one employee is 0.9325 , which confirms the close links between these indicators. The functional dependence of labor productivity on the fixed capital per worker at the agricultural enterprises based on data for 2008-2017 is presented in Figure 5.

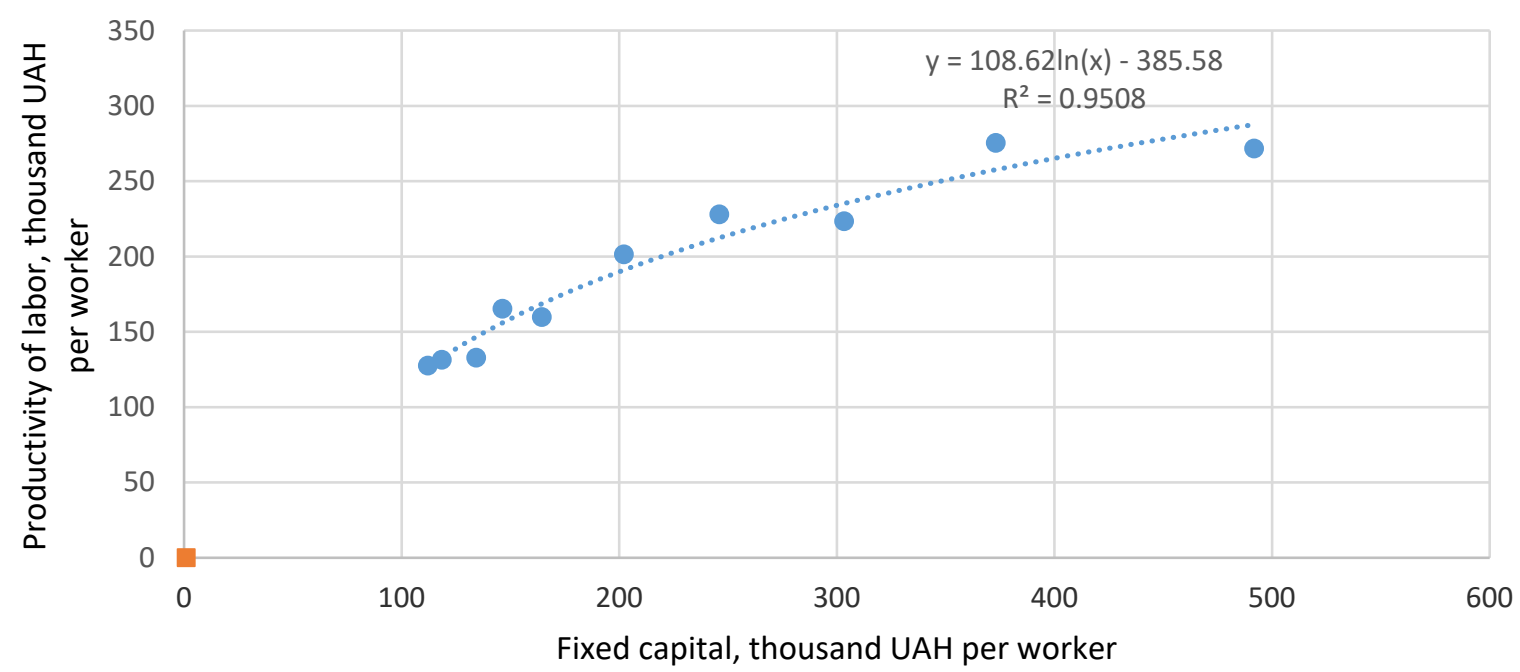

Figure 5. The dependence of labor productivity (y) on fixed capital per worker $(\mathrm{x})$ in agricultural enterprises in Ukraine

Source: Developed by authors

The modification of this function showed that the logarithmic function ( $R 2=0.9598)$ better describes the relationship between labor productivity and fixed capital (in particular, for linear function $\mathrm{R} 2=0.874$ ).
Labor productivity growth occurred under the increase of main crops (grain, sugar beet, sunflower, soybeans, potatoes, vegetables, fruits, and nuts) yield in Ukraine (Figure 6). The tightest correlation is between labor productivity and yield of grain crops $(0,904)$. 


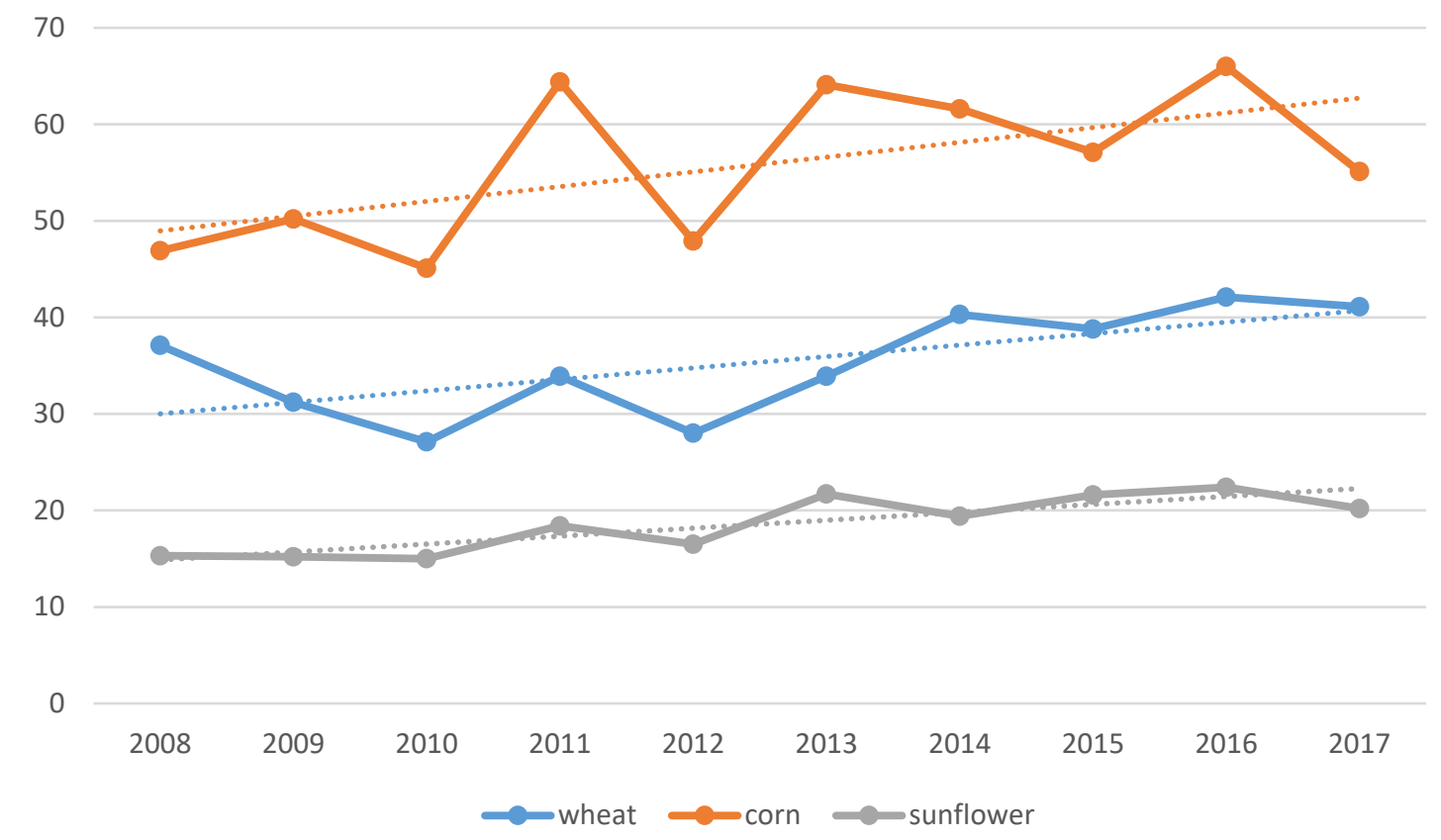

Figure 6. Yield of wheat, corn, sunflower in Ukraine, centners per hectare of the harvested area Source: Developed by authors using data of State Statistical Service of Ukraine

The tight correlation between labor productivity and fixed capital per worker, a yield of grain gives ground for the construction of the regression model:

$$
y=-26691.7+246.0 x+4366,0 g,
$$

where y - labor productivity, UAH per worker, $\mathrm{x}$ - fixed capital, thousand UAH per worker, $\mathrm{g}$ yield of grain, centners per hectare.

$\mathrm{R}^{2}=0.960$ for this model is very high. The relevant F-statistics for the significance of the variables of the model are calculated and compared with the critical tabulated values. The estimated F-statistics values are greater than the critical values, so, the chosen variables of the model are meaningful for describing their dependence on labor productivity.

Thus, export-oriented production, favorable price dynamics, and the profitability of agricultural production caused the increase of investments, fixed capital, as well as the implementation of new technologies, and more productive and reliable crop seeds, and contributed to labor productivity doubling during the last ten years in Ukrainian agricultural enterprises.

\section{RESULTS OF COMPARATIVE ANALYSIS OF LABOUR PRODUCTIVITY}

An assessment of the level of labor productivity in the United States and Ukraine answers the question of whether the growth of labor productivity in agriculture in Ukraine was sufficient to reach the level of developed countries like the USA.

The data from Census 2017 was used to assess the productivity of U.S. labor in agriculture (Table 4). 
Table 4. Labor productivity in agriculture in the USA in 2017

\begin{tabular}{|l|r|}
\hline Indicators & 2017 \\
\hline Market value of agricultural product sold, \$ million & $388,522.695$ \\
\hline Producers, person & $3,447,028$ \\
\hline Productivity of labor, \$ product sold per producer & 112,712 \\
\hline
\end{tabular}

Source: authors' calculations using of Census of Agriculture 2017 data

The seasonality of production, part-time employment, and the existence of unofficial employment lead to the inaccuracy in the calculation of labor productivity in agriculture. But such peculiarities of employment are characteristics of both American farms and Ukrainian agriculture.
An assessment of labor productivity (in current prices) in agriculture in Ukraine and at agricultural enterprises was done for three years $(2015,2016$, and 2017) due to the significant fluctuations in production output and the national currency exchange rate. (Table 5).

Table 5. Labor productivity in agriculture in Ukraine

\begin{tabular}{|l|r|r|r|}
\hline \multicolumn{1}{|c|}{ Indicators } & \multicolumn{1}{c|}{$\mathbf{2 0 1 5}$} & $\mathbf{2 0 1 6}$ & \multicolumn{1}{c|}{$\mathbf{2 0 1 7}$} \\
\hline Output in agriculture, UAH million. & 544,206 & 637,791 & 707,792 \\
\hline Output at agricultural enterprises, UAH million & 327,346 & 387,277 & 428,399 \\
\hline Exchange rate, UAH/ US\$ & 21.8447 & 25.5513 & 26.5966 \\
\hline Output in agriculture, \$ million & 24,945 & 24,961 & 26,612 \\
\hline Output at agricultural enterprises, \$ million & 14,985 & 15,157 & 16,107 \\
\hline Employees, thousand & 2,863 & 2,855 & 2,853 \\
\hline Hired workers, thousand & 500.9 & 513,2 & 496.1 \\
\hline Labor productivity in agriculture, \$ per employee & 8,702 & 8,731 & 9,328 \\
\hline $\begin{array}{l}\text { Labor productivity at agricultural enterprises, \$ } \\
\text { per hired worker }\end{array}$ & 29,916 & 29,534 & 32,468 \\
\hline
\end{tabular}

Source: authors' calculations

According to the results of the calculations, the highest level of labor productivity for the last three years, estimated in U.S. dollars, was achieved in Ukraine in 2017. However, despite the rich resource potential of agricultural production and more than two times increasing labor productivity at the agricultural enterprises in Ukraine over the past ten years, the level of labor productivity in agriculture in Ukraine is still at least 12 times (\$9 328 against $\$ 112712$ ) lower than that on American farms. Also, labor productivity at the agricultural enterprises in Ukraine is still 3.5 times lower compared to the achieved level on American farms (\$32 468 versus \$112 712 per worker).

\section{CONCLUSIONS AND RECOMMENDATION}

The trends in investment and labor productivity in agriculture in Ukraine have been influenced by dominant political and macroeconomic factors as well as specific factors of agricultural production and international agricultural commodity markets in 2008-2017. Although the economy of Ukraine did not restore the 2008 level of GDP in 2017 after the macroeconomic crises, the annual volume of investment (estimated in national currency) in agriculture in 2017 was larger than 2008 by 3.9 times.

The growth of investment in agriculture was dependent on the growth of the economy, but 
also investment was strongly influenced by the agricultural product prices and the amount of profit received by agricultural enterprises. Investments provided an increase of fixed capital in agriculture. The fixed capital (in the Ukrainian currency) per one employed increased by 3.6 times in 2008-2017 in agriculture, and 4.4 times - at the agricultural enterprises. The amount of fixed capital (in U.S. dollars) per unit of labor had a significant reduction in the years of crisis with subsequent gradual build-up. The fixed capital (in U.S. dollars) per unit of labor did not recover again in 2017 compared to 2008. The value of fixed capital per worker in agriculture in Ukraine is much lower than that of developed countries, but it is on the average world level.

The increase of the fixed capital per worker caused the labor productivity growth in agricultural enterprises. Despite the crisis, labor productivity has doubled at Ukrainian agricultural enterprises over the decade. The dependence of labor productivity on the level of fixed capital per worker, a yield of grains at agricultural enterprises, was confirmed by the regression model.

The decline in agricultural production was not as significant as the fall in GDP during 20082017 in Ukraine. In 2016 the volume of agricultural production was almost 30 percent higher than in 2008 (at agricultural enterprises - by 46.2 percent). So, during the macroeconomic crises, agriculture played an important role as the buffer in the Ukrainian economy. Besides, it provided food security and, its export contributed to a supply of foreign currency and reduced the fall of the national currency.

Further increasing labor productivity will contribute to the realization of the full economic potential of agricultural production, and improvement of the capacity of agriculture to respond to multiple challenges. This requires micro- and macrolevels efforts addressing longterm issues of sources of productivity growth (first of all, support of generation and implementation of innovations, accumulation of human capital) and consequences (prevention of negative impacts of farming on the natural environment, security of quality and safety of agricultural product, increase the opportunities for labor to reallocate).

\section{REFERENCES}

Agricultural Statistics 2017, United States Department of Agriculture, National Agricultural Statistical Service. Washington DC: United States government printing office, $512 \mathrm{p}$. https://www.nass.usda.gov/Publications/Ag _Statistics/2017/Complete\%20Ag\%20Stats\%2 02017.pdf/. Date of access: 17.06.2019.

Agriculture of Ukraine 2017. (2018): Statistical Yearbook. Kyiv: State Statistics Service of Ukraine.

Alston, J.M., Beddow, J.B., \& Pardey, P.G. (2009). Agricultural Research, Productivity, and Food Prices in the Long Run, Science 325, 4. 1209-1210.

Blanco, C. \& Raurichy, X. (2018). Agricultural Composition, Structural Change and Labor Productivity. Meeting Papers of Society of Economic Dynamics.

https://economicdynamics.org/meetpapers/ 2018/paper_772.pdf. Date of access: 14.08.2019.

Census of Agriculture 2017. United States. Summary and States DATA (2019). Volume 1 / USDA, Sonny Perdue/ NASS, Hubert Hammer. Washington DC, 2019. Retrieved June 17, 2019 from. https://www.nass.usda.gov/Publications/Ag Census/2017/Full_Report/Volume_1,_Chapte r_1_US/usv1.pdf/. Date of access: 17.06.2019.

Chen, C., Restuccia, D., \& Santaeulàlia-Llopis, R. (2019). The Effects of Land Markets on Resource Allocation and Agricultural Productivity. National Bureau of Economic Research. Working Papers Series. http://www.nber.org/papers/w24034. Date of access: 17.12.2019.

Cobb, C. W. \& Douglas, P.H. (1928) A Theory of Production. American Economic Review, 18 (1), 139-168.

Diyesperov, V. (2003). Productivity of Labor in Agriculture. Economy of Ukraine. 11, 61-68. (Original work written in Ukrainian). 
FAO (2018). Transforming food and agriculture to achieve the SDGs. 20 interconnecting actions to guide decision-makers. Technical Reference Document. Rome. 132 p.

FAO (2012). The State of food and agriculture. Investing in agriculture for a better future. Rome. 182 p.

FAO (2019). Food Price Index. http://www.fao.org/worldfoodsituation/foo dpricesindex/en/. Date of access: 18.06.2019.

Fuglie, K., MacDonald, J. M., \& Ball, V. E. (2007). Productivity Growth in U.S. Agriculture. USDA-ERS Economic Brief No. 9. Available at SSRN: https://ssrn.com/abstract $=1084980$ or http://dx.doi.org/10.2139/ssrn.1084980 Date of access: 18.06.2019.

Herrendorf, B. \& Schoellman, T. (2015). Why is measured productivity so low in agriculture? Review of Economic Dynamics, 18 (4), 1003-1022. https://doi.org/10.1016/j.red.2014.10.006.

Iscan, T.B. Allocative Inefficiency and Sectoral Allocation of Labor: Evidence from U.S. Structural Transformation. Dalhousie University, Working Paper \#2012.02. https://www.researchgate.net/publication/2 67797908_Allocative_Inefficiency_and_Sect oral_Allocation_of_Labor_Evidence_From_U S_Structural_Transformation. Date of access: 18.12.2019.

Kawagoe, T., Hayami, Yu., \& Ruttan, V. W.(1985). The intercountry agricultural production function and productivity differences among countries. Journal of Development Economics, 19(1-2). 113-132. https://doi.org/10.1016/03043878(85)90041-0

Lupenko, Yu.O. \& Zakharchuk, O.V. (2018). Investment provision of innovative development of Ukrainian agriculture, Ekonomika APK, 11, 9-18. (Original work written in Ukrainian). DOI: https://doi.org/10.32317/22211055.201811009

OECD. Trends in agricultural productivity and sustainability performance http://www.oecd.org/agriculture/topics/agri cultural-productivity-and-innovation/. Date of access: 13.03.2019.
Restuccia, D. (2016). Resource Allocation and Productivity in Agriculture. https://www.economics.utoronto.ca/diegor/ research/Restuccia_ResAlloc_Oxford.pdf. Date of access: 13.08.2019.

Restuccia, D. \& Rogerson, R. (2013). Misallocation and productivity. Review of Economic Dynamics, 16 (1), 1-10. https://doi.org/10.1016/j.red.2012.11.003

Restuccia, D., Yang \& D.T., Zhu, X. (2008). Agricultural and aggregate productivity: a quantitative cross-country analysis. Journal of Monetary Economics, 55 (2), 234-250. https://doi.org/10.1016/j.jmoneco.2007.11.0 06. Date of access: 13.03.2019.

Schultz, T.W. (1956). Reflection on Agricultural Production, Output and Supply. American Journal of Agricultural Economics, 38 (3), 748-762. https://doi.org/10.2307/1234459

State Fiscal Service of Ukraine. (2020). http://sfs.gov.ua/ms/f11

Schultz, T.W. (1945). Agriculture in Unstable Economy. New York, McGraw Hill. 299p.

United Nations. Transforming our world: the 2030 Agenda for Sustainable Development (2015). Document of the United Nations General Assembly. http://www.un.org/ga/search/view_doc.asp ?symbol=A/70/L.1\&Lang=E/. Date of access: 21.03.2019.

Vitvitsky V.V. \& Avramenko Yu.O .(2018). Productivity and competitiveness management in agrarian enterprises in the context of socio-economic development goals. Ekonomika APK, 5, 100-109. (Original work written in Ukrainian).

Vitvitskyi, V.V. (2018). Institutional environment of productivity's management in the agrarian sector of the economy.

Ekonomika APK, 8, 107-115. (Original work written in Ukrainian).

Wang, S.L., Paul Heisey, P., Schimmelpfennig D., \& Ball, E. (2015). Agricultural Productivity Growth in the United States: Measurement, Trends, and Drivers, ERR-189, U.S. Department of Agriculture, Economic Research Service, July 2015. https://ethanolrfa.org/wpcontent/uploads/2017/07/Agricultural- 
Productivity-Growth-in-the-US_Wang-etal_2015.pdf/. Date of access: 21.05.2019.

Yasmin, T., El Refae, G., \& Eletter, S. (2019). Sectoral productivity in Hungarian economy: an input-output linkages approach. Journal of Eastern European and Central Asian Research, 6 (2), 344-355.

Zadorozhna, L. (2014). Forming Agro Industries Clusters for Reaching Competitiveness of Ukrainian Agroindustrial Sector. Journal of Eastern European and Central Asian Research, 1 (1), 2-11.

Zakharchuk, O.V. (2019). Technical maintenance of agricultural enterprises in Ukraine.

Ekonomika APK, 2, 48-56. (Original work written in Ukrainian). https://doi.org/10.32317/22211055.201902048.

\section{ABOUT THE AUTHORS}

Viktoriya Onegina, email: viconeg1511@gmail.com

Dr. Viktoriya Onegina holds the Ph.D. in Economics, Professor, Head of Economics, and Marketing Department of Kharkiv Petro Vasylenko National Technical University of Agriculture (Kharkiv, Ukraine). Her experience of teaching, scientific research in the Higher Education System is more than 20 years. The author more than 200 scientific papers, seven textbooks, seven monographs. Scientific interests are focused on agricultural policy, fiscal policy, innovation, and investment management. She is a member of the editorial board of 3 scientific journals, a participant of the International Education and Research Exchange Programs (Faculty Exchange Program of USDA: Fulbright Scholar Program), many International Scientific Conferences. She was awarded by "Gratitude Letters" from Ministry of Education and Science of Ukraine, Ministry of Agricultural Policy and Food of Ukraine.

Dr. Nikolay Megits is a Professor of Economics at the School of Business and Technology of Webster University, St. Louis, MO. He is an expert in global economics, strategic management, FDI in emerging markets, and entrepreneurship, with a distinguished record of academic achievement in lecturing and scholarly research. He possesses over 25 years of international business experience, including strategic planning, sales, and import/export practices. He holds an MBA and a Doctorate in Economics. Dr. Megits is an Academic of the Ukrainian Academy of Economic Sciences.

Dr. Vitalina Antoshchenkova holds the Ph.D. in Economics, Associate Professor of Economics and Marketing Department of the Kharkiv Petro Vasylenko National Technical University of Agriculture. The author of 65 scientific papers, including five monographs and two textbooks. He has experience of teaching and scientific research in the system of higher education for more than ten years, developed the curriculum and courses for distance education, participated in the many International scientific conferences; she is an excellent consultant students' scientific activities. The area of her scientific research is concentrated on the pricing and efficiency of dairy production, the competitiveness of dairy products.

Dr. Olexandr Boblovskyi, is the Associate Professor at the Department of Organization of Production, Business and Management of the Kharkiv Petro Vasylenko National Technical University of Agriculture. His scientific interests include resource-saving technologies for growing crops, intercultural interaction in the conditions of globalization, green tourism, business planning. More than 90 scientific papers have been published in scientific journals of the Kharkiv Petro Vasylenko National Technical University of Agriculture, National Agrarian University, Lviv National Agrarian University, Kharkiv V. Karazin National University Tavrida State Agritechnological University, and in the International journal Espacios, which is indexed in Scopus. 
